\title{
Benzyladenine Affects Cell Division and Cell Size during Apple Fruit Thinning
}

\author{
Paul T. Wismer and J.T.A. Proctor \\ Department of Horticultural Science, University of Guelph, Guelph, Ontario, N1G 2W1, Canada \\ D.C. Elfving ${ }^{1}$ \\ Horticultural Research Institute of Ontario, Vineland Station, Ontario, LOR 2EO, Canada
}

Additional index words. auxin, cytokinin, Malus domestica, NAA, carbaryl, daminozide

\begin{abstract}
Benzyladenine (BA), carbaryl (CB), daminozide (DM), and naphthaleneacetic acid (NAA) were applied postbloom as fruitlet thinning agents to mature 'Empire' apple (Malus domestica Borkh.) trees. BA, NAA, and CB reduced fruit set and yield per tree, and increased fruit size, percent dry weight, soluble solidscontent and return bloom. Fruit size was reduced, return bloom, length : diameter ratio and flesh firmness were increased, and fruit set and yield unaltered by DM. Although fruit set and yield were similar for BA, NAA, and CB, BA treated fruit were larger, indicating that BA increased fruit size beyond the effect attributable to chemical thinning alone. BA increased the rate of cell layer formation in the fruit cortex, indicating that BA stimulated cortical cell division. NAA, CB and DM had no effect on cell division rate. Mean cortical cell diameter at harvest was increased by NAA and CB and reduced by DM. Cell diameter at harvest in BA-treated fruit was similar to the control. These data support the hypothesis that BA-induced fruit size increase in 'Empire' apple results from greater numbers of cells in the fruit cortex, whereas the fruit size increase due to NAA or CB is a consequence of larger cell size. Chemical names used: $N$ - (phenylmethyl)-1H-purine-6-amine [benzyladenine (BA)]; 1-napthaleneacetic acid (NM); 1naphthalenyl methylcarbamate [carbaryl (CB)]; butanedioic acid mono (2,2dimethyl hydrazide) [daminozide (DM)].
\end{abstract}

Fruitlet thinning is an essential part of the commercial production of quality apples. Blossom or fruitlet thinning early in the season improves fruit size at harvest and increases return bloom, thereby reducing the biennial bearing habit of apple trees (Westwood, 1993).

The cytokinin benzyladenine (BA) is now registered for use as a chemical thinner for apple as a formulation containing both BA and gibberellic acid (Abbott Laboratories, 1993). BA effectively thins many cultivars, including 'Empire' (Elfving and Cline, 1993a, 1993b; Greene et al., 1990) 'McIntosh', (Greeneand Autio, 1989), 'Golden Delicious' (Greene et al, 1990), and 'Idared' (Elfving, 1989). BA thins most cultivars at concentrations from 25 to $100 \mathrm{mg} \cdot \mathrm{liter}^{-1}$ (Bound et al., 1991; Byers and Carbaugh, 1991; Elfving, 1991; McLaughlin and Greene, 1984). BA also increases return bloom in many apple cultivars (Bound et al., 1991; Elfving and Cline, 1993a, 1993b; Greene et al, 1990) and increases fruit size more than would be expected from thinning alone (Greene et al., 1992; McLaughlin and Greene, 1984).

Cytokinins promote cell division in apple tissue (Letham, 1958) and cell division is still underway in fruits when BA is applied for thinning (Denne, 1963a, 1993b; Schechter et al, 1993a, 1993b). These circumstances have led to speculation that BA used as a thinner may affect the rate and/or duration of cell division in the apple fruit. The objective of this investigation was to examine the effect of BA used as a chemical thinner on cell division and cell size in 'Empire' apple in comparison to the chemical thinners

Received for publication 23 Dec. 1994. Accepted for publication 14 Apr. 1995. This research was supported by operating grant no. A6697 of the Natural Sciences and Engineering Research Council (NSERC) of Canada held by J.T.A.Proctor and an NSERC graduate scholarship held by Paul T. Wismer. We gratefully acknowledge the assistance of Larry Peterson, Dean Louttit, Jean Gerrath, Mary Born, and David Percival. Mention of a product or trade name does not constitute a guarantee or warranty of the product by the Univ. of Guelph or the Horticultural Research Institute of Ontario nor an endorsement over similar products not mentioned. The cost of publishing this paper was defrayed in part by the payment of page charges. Under postal regulations, this paper therefore must be hereby marked advertisement solely to indicate this fact.

'Present Address: Tree Fruit Research and Extension Center, Wash. State Univ., 1100 N. Western Avenue, Wenatchee, WA 98801. naphthaleneacetic acid (NAA) and carbaryl (CB) and the growth regulator daminozide (DM), which inhibits cell division in apple under some circumstances (Martin et al., 1968).

\section{Materials and Methods}

All trees used for this investigation were mature, annually bearing 'Empire' growing at the Horticultural Research Institute of Ontario Horticultural Experiment Station in Simcoe, Ontario. The trees were growing in north-south rows and were trained to a conventional central leader form (Tehrani et al., 1988). Standard commercial practices for fertilization and pest control were followed (Ontario Ministry of Agriculture and Food, 1990).

BA effects, Expt. 1. In 1990 a block of 68 lo-year-old 'Empire'/ M.26 trees spaced at $3.7 \times 5.5 \mathrm{~m}$ was used. The trees were of similar size and bloom density, and the single-tree plots were distributed in a completely randomized design. Full bloom occurred on 9 May. On 31 May (mean fruit diameter $10.5 \pm 1.4 \mathrm{~mm}$ ), 20 or 30 trees were each sprayed to the drip point with 50 or $100 \mathrm{mg} \cdot$ liter $^{-1} \mathrm{BA}$ (ABG-3062, Abbott Laboratories, North Chicago, Ill.), respectively. This formulation contains no gibberellic acid. The remaining 18 trees were left unsprayed to serve as control. More trees were used in the two chemically thinned groups than in the control group to avoid excess fruit load reduction from repeated removal of fruit samples for microscopic tissue analyses. At final harvest all fruit from each tree were counted and weighed to determine total yield per tree. The number of normally developed seeds per fruit was counted in a 30-fruit sample from each treatment. In Spring 1991, one representative limb per tree was selected, the circumference measured and all bloom clusters counted (Forshey and Elfving, 1979a, 1979b; Lombard et al., 1988).

Chemical thinner effects, Expt. 2. In 1991 a block of lo-yearold 'Empire'/M.7 trees spaced at $4.9 \times 6.7 \mathrm{~m}$ was used. Trees were grouped into ten randomized complete-blocks of five trees according to tree size, bloom density and location. Before bloom, one representative limb 12 to $15 \mathrm{~cm}$ in circumference was tagged on each tree for use in bloom and fruit set counts (Forshey and Elfving, 1979a, 1979b). Full bloom occurred 13 May. On 27 May (mean 
fruit diameter $13.1 \pm 1.4 \mathrm{~mm}$ ), one tree in each block was sprayed with either BA $100 \mathrm{mg} \cdot$ liter $^{-1}$ (ABG-3062), NAA $15 \mathrm{mg} \cdot \mathrm{liter}^{-1}, \mathrm{CB}$ $1000 \mathrm{mg} \cdot$ liter $^{-1}$ or DM 1500 mgliter'. The fifth tree in each block was not sprayed and served as the control. Blossom clusters were counted on each tagged limb before full bloom and the number of fruit counted after June drop.

At final harvest the total number and weight of fruit on each tree were recorded. Twenty fruit per tree were sampled for length, diameter, fresh and dry weight measurements. Fruit length and diameter were measured by laying the fruit end-to-end and side-toside in a V-shaped trough and measuring total length and diameter. After removing the pedicel, each fruit was weighed fresh (FW) and then cut into slices and oven-dried to a constant dry weight (DW) at $80 \mathrm{C}$. Ten of these same fruit were cut and the numbers of aborted and apparently viable seeds were determined. For the remaining 10 fruit, flesh firmness was determined with a penetrometer (Effegi, Alfonsine, Italy; tip diameter $11.1 \mathrm{~mm}$ ) on two sides of each fruit. Juice was collected during the firmness test and soluble solids content (SSC) was determined on a composite sample using a hand refractometer (Fisher Scientific, Unionville, Ont.). Return bloom counts were taken on the tagged limbs in spring 1992.

Cell division and diameter, Expt. 1. To examine the number of cell layers and cell diameter in the fruit cortex, five well exposed fruit from 1 to $2 \mathrm{~m}$ height in the canopy were harvested randomly from each treatment on each sample date and preserved and stored in formalin-acetic acid-alcohol (FAA) [per $100 \mathrm{ml}: 50 \mathrm{ml}$ ethanol (95\%), $5 \mathrm{ml}$ glacial acetic acid, $10 \mathrm{ml}$ formalin (37\% formaldehyde), $35 \mathrm{ml}$ distilled water] (O’Brien and McCully, 1981). Small fruits were preserved whole, while larger fruits were cut into pieces to allow for rapid fixation of the inner tissue. The samples were preserved so fruit cortex tissue could be examined at the cellular level at a later date following embedding, sectioning and staining of the tissue.

For paraffin embedding and microtome sectioning, whole apples or apple pieces were removed from the FAA and rinsed in running water for $5 \mathrm{~min}$. Equatorial transverse sections 3 to $4 \mathrm{~mm}$ thick were cut from each apple. For small apples $(<2.5 \mathrm{~cm}$ in diameter $)$ the whole disc was used, while for larger fruit, 2 quarters of the disc from opposite sides of the fruit were used. Discs were held in $70 \%$ ethanol until the paraffin embedding procedure began. The tissue discs were dehydrated in a graded alcohol series and cleared with xylene, embedded in paraffin and sectioned at 5 to $10 \mu \mathrm{m}$ on a rotary microtome (Leica 1512, Willowdale, Ont.). Sections were stained with the periodic acid/Schiff's reaction (O'Brien and McCully, 1981) and permanent mounts made.

Using a light microscope (Zeiss Photomicroscope III, Oberkschen, W. Germany, magnification 63 to $400 \times$ ), the number of cell layers in the cortex was determined using methodology similar to Denne (1960). For each apple the number of cells in a radial line from a sepal vascular strand and from a neighboring petal vascular strand to the epidermis was counted. Four counts were made per fruit, two from each side of the fruit. Cortex width was determined by measuring the distance from the same vascular strands to the epidermis. The mean radial cell diameter was calculated from width of the cortex divided by mean number of cells across the cortex.

In 1991, fruit sampling was similar to that of 1990. Fruit sampling began at full bloom and at each sample date six fruit per treatment were harvested randomly. For fruit sampled up to 35 days after full bloom (DAFB), the paraffin embedding procedure and cellular analysis were the same as used in 1990. For fruit sampled 35 DAFB and later, sections were prepared by hand.

Hand sectioning. Fruit were removed from FAA and rinsed in running water for $5 \mathrm{~min}$. Fruit were cut in half along the equatorial plane with a razor blade. One half was used for hand-sectioning and the other was returned to FAA. The apple half was cut in half longitudinally. For each apple quarter a razor blade was used to cut avery thin equatorial section about $1 \mathrm{~mm}$ thick. The distances from one sepal vascular strand and a neighboring petal vascular strand to the epidermis were measured using a hand magnifying lens $(7 \mathrm{x})$ equipped with an ocular micrometer (i.e., two measurements per apple quarter, four per fruit). Hand sections were cut with a razor blade from the mid-cortical tissue between each of the vascular strands and the epidermis used to determine cortex width. Cells in the mid-cortical tissue are representative of the mean cell diameter of the cortical tissue (Bain and Robertson, 1951). Sections were stained with toluidine blue as required and placed on microscope slides in a solution of $70 \mathrm{ml}$ glycerin : $30 \mathrm{ml}$ distilled water. The radial diameter of 60 cells was measured for each vascular strand ( 240 cells per fruit) by examining the slides under a light microscope equipped with an ocular micrometer (magnification 100 to $400 \times$ ). The mean cell diameter was calculated for each vascular strand. The number of cell layers was calculated by dividing the cortex width by mean cell size for each vascular strand.

All analyses were carried out using the General Linear Models (GLM) procedure of the Statistical Analysis System (SAS) program package (SAS Institute, Cary, N.C.). In 1990, data from all replicated results were subjected to orthogonal-contrast analysis of linear and quadratic components of BA concentration using the General Linear Models (GLM) program of the SAS statistical package. All variables had a normal distribution and no transformations were necessary. Full bloom was designated as day zero (0) and days were counted thereafter as DAFB .

Results from 1991 were subjected to analysis of variance or regression using the General Linear Models (GLM) program of the SAS statistical package. All variables were tested for normal distribution to determine if transformation of the data was necessary. Logarithmic and arcsin transformations were used as needed and the analysis of variance and mean separation procedures were repeated with the transformed data. Treatment means were separated using the Ryan-Einot-Gabriel-Welsch multiple F test at $P \leq$ 0.05 (SAS). The relationships between number of cell layers and cell diameter to DAFB were analyzed using quadratic and cubic regression models. Comparisons between the intercepts and linear components (slope) of regression lines were carried out using single-degree-of-freedom contrasts. Mean values of number of cell layers and cell diameter on the last sample date were separated by single-degree-of-freedom contrasts.

\section{Results and Discussion}

In 1990 (Expt. 1), BA reduced both fruit number and fruit weight per tree linearly as the concentration of BA increased (Table 1), similar to previous observations with 'Empire' (Elfving and Cline, 1993a, b; Greene et al., 1990), 'McIntosh' (Greene and Autio, 1989), and 'Idared' (Elfving, 1989) apples. The large increase in mean fruit weight induced by BA was not sufficient to offset the effect of reduced fruit number per tree on total yield (Elfving and Schechter, 1993; Forshey and Elfving, 1977). BA had no effect on seed number per fruit but increased return bloom (Elfving and Cline 1993a, b; Greene and Autio, 1989; McLaughlin and Greene, 1984).

In 1991 (Expt. 2), bloom was uniform and heavy, averaging 13.5 bloom clusters per square centimeter limb cross-sectional area (data not shown). BA, NAA, and CB significantly reduced fruit set, yield and increased mean fruit weight compared to the control (Table 2). BA produced a larger mean fruit weight than 
Table 1. Effect of benzyladenine (BA) on yield and fruit characteristics of 'Empire' apples at harvest in 1990 and return bloom in 1991 (Expt. 1).

\begin{tabular}{|c|c|c|c|c|c|}
\hline $\begin{array}{l}\text { BA } \\
\text { concn } \\
\left(\mathrm{mg} \cdot \text { liter }^{-1}\right)^{2}\end{array}$ & $\begin{array}{c}\text { Fruit } \\
\text { no. per } \\
\text { tree }\end{array}$ & $\begin{array}{c}\text { Yield } \\
\text { (kg/tree) }\end{array}$ & $\begin{array}{l}\text { Mean } \\
\text { fruit wt } \\
\quad(g)\end{array}$ & $\begin{array}{l}\text { Seeds/ } \\
\text { fruit }\end{array}$ & $\begin{array}{c}\text { Return bloom } \\
1991 \\
\text { (clusters } / \mathrm{cm}^{2} \operatorname{LCSA}^{x} \text { ) }\end{array}$ \\
\hline 0 & 712 & 115 & 165 & 6.3 & 7.9 \\
\hline 50 & 524 & 101 & 195 & 5.5 & 11.7 \\
\hline 100 & 467 & 94 & 204 & 5.8 & 13.9 \\
\hline \multicolumn{6}{|l|}{ Significance $^{y}$} \\
\hline $\mathrm{L}$ & $* * * *$ & $* * * *$ & $* * * *$ & NS & $* * * * *$ \\
\hline$Q$ & NS & NS & $*$ & NS & NS \\
\hline
\end{tabular}

${ }^{2}$ Treatments were applied 22 days after full bloom (mean fruit diameter $10.5 \pm 1.4 \mathrm{~mm}$ ). Observations per mean: BA0: 18, BA50: 20, BA100: 30.

'Means analyzed by single-degree-of-freedom contrasts.

${ }^{x} \mathrm{LCSA}=$ limb cross-sectional area.

Ns $*, * * * *$ Effect nonsignificant or significant at $P \leq 0.05$ or 0.0001 , respectively.

either NAA or CB, although fruit set and yield were comparable among thinning treatments. DM did not affect fruit set or yield, but DM-treated fruit were smaller than control fruit and showed a slightly increased length : diameter $(\mathrm{L}: \mathrm{D})$ ratio. All three thinning treatments produced fruit with a greater percent dry weight than untreated fruit, while the percent dry weight of DM-treated fruit did not differ from the control. None of the treatments had an effect on seed number per fruit (data not shown) and all treatments increased return bloom the following spring. DM increased flesh firmness over control while CB decreased it; the other treatments had no effect on firmness. Soluble solids were increased by all thinning treatments relative to DM and control.

Cell layer formation. In 1990 (Expt. 1), the number of cell layers present at the time of BA application (22 DAFB) was similar among treatments (Fig. 1). The number of cell layers increased curvilinearly up to 49 DAFB in all treatments; the number of cell layers was increased in proportion to concentration of BA applied, indicating that cell division had been increased in BA-treated fruit. In 1991 (Expt. 2), the number of cell layers present 53 DAFB was significantly increased only by BA (Table 3 ). The numbers of cell layers in all other treatments were comparable to the control. Cell diameter was the same for all treatments at 53 DAFB, but was significantly larger in CB- and NAA-treated fruit at harvest (134 DAFB). At harvest, mean cell diameter in BA-treated fruit was similar to the control but was smaller than control in DM-treated fruit.

In 1991 (Expt. 2), the number of cell layers increased curvilinearly from shortly after bloom to 53 DAFB (Fig. 2). The rate of change. in number of cell layers was similar for all treatments except BA, in which the number of cell layers in- creased more rapidly during the cell-division phase. By 53 DAFB, the number of cell layers had reached its maximum for all treatments and was similar in control, NAA-, CB- and DM-treated fruit. Similar regression analyses over the entire growing season indicated that the rate of cell expansion in 1991 did not differ from the control for any treatment (data not shown), although both DM and BA treatments decreased the rate of cell expansion relative to NAA and CB.

Cytokinins promote cell division in plant tissues (Gardner et al., 1985; Letham, 1958), stimulate the growth of apple fruit tissue in sterile culture (Letham, 1958), and promote the growth of developing apple fruitlets (Letham, 1963). Cell division is underway in the fruitlet at the time BA is applied as a thinner (Denne, 1963a, 1963b; MacArthur and Wetmore, 1941); stimulation of this process by BA application would produce an increase in the number of cells in the fruit. BA increased the number of cell layers in the fruit cortex in both 1990 and 1991, while CB, DM, and NAA had no effect on cell numbers in 1991.

The number of cells in an apple may be increased in three ways: 1) by more rapid cell division during the cell-division phase of fruit growth, 2) by extending cell division for a longer period than normal, or 3) by some combination of these two phenomena. The results of this trial suggest that a single application of BA for chemical thinning increased the rate of cell division in the fruit cortex but did not influence the duration of that process. Early-season hand thinning may stimulate cell division (Denne, 1960; Martin et al., 1964; Westwood et al., 1967). However, chemically thinning with $\mathrm{NAA}$ or $\mathrm{CB}$ at the normal timing produced no effect on fruit

Table 2. Effects of daminozide (DM), benzyladenine (BA), naphthaleneacetic acid (NAA), and carbaryl (CB) on yield and fruit characteristics of 'Empire' apples at harvest in 1991 and return bloom in 1992 (Expt. 2).

\begin{tabular}{|c|c|c|c|c|c|c|c|c|}
\hline $\begin{array}{l}\text { Treatment } \\
\left(\mathrm{mg} \cdot \mathrm{liter}^{-1}\right)^{\mathrm{z}, y}\end{array}$ & $\begin{array}{c}\text { Fruit } \\
\text { set } \\
\left(\text { no. } / \mathrm{cm}^{2} \mathrm{LCSA}^{\mathrm{x}}\right)\end{array}$ & $\begin{array}{c}\text { Yield } \\
(\mathrm{kg} / \text { tree })\end{array}$ & $\begin{array}{l}\text { Mean } \\
\text { fruit wt } \\
\text { (g) }\end{array}$ & $\begin{array}{l}\text { Dry wt } \\
(\%)\end{array}$ & $\begin{array}{l}\mathrm{L}: \mathrm{D} \\
\text { ratio }\end{array}$ & $\begin{array}{c}\text { Soluble } \\
\text { solids concn } \\
(\%)\end{array}$ & $\begin{array}{l}\text { Flesh } \\
\text { firmness } \\
(\mathrm{N})\end{array}$ & $\begin{array}{c}\text { Return bloom } \\
\text { in } 1992 \\
\text { (clusters } / \mathrm{cm}^{2} \\
\text { LCSA) }\end{array}$ \\
\hline Control & $10.3 \mathrm{a}$ & $154 \mathrm{a}$ & $113 \mathrm{c}$ & $13.8 \mathrm{~d}$ & $0.84 \mathrm{~b}$ & $11.9 \mathrm{~b}^{\mathrm{y}}$ & $76.8 \mathrm{~b}$ & $4.4 \mathrm{c}$ \\
\hline DM 1500 & $10.4 \mathrm{a}$ & $146 \mathrm{a}$ & $98 \mathrm{~d}$ & $13.9 \mathrm{~cd}$ & $0.85 \mathrm{a}$ & $11.8 \mathrm{~b}$ & $84.6 \mathrm{a}$ & $9.0 \mathrm{~b}$ \\
\hline BA 100 & $4.0 \mathrm{~b}$ & $92 \mathrm{~b}$ & $159 \mathrm{a}$ & $14.8 \mathrm{a}$ & $0.84 \mathrm{~b}$ & $12.4 \mathrm{a}$ & $75.2 \mathrm{bc}$ & $12.9 \mathrm{ab}$ \\
\hline NAA 15 & $4.0 \mathrm{~b}$ & $83 \mathrm{~b}$ & $133 \mathrm{~b}$ & $14.4 \mathrm{ab}$ & $0.83 \mathrm{~b}$ & $12.2 \mathrm{a}$ & $76.4 \mathrm{bc}$ & $13.6 \mathrm{a}$ \\
\hline CB 1000 & $4.5 \mathrm{~b}$ & $97 \mathrm{~b}$ & $139 \mathrm{~b}$ & $14.3 \mathrm{bc}$ & $0.83 \mathrm{~b}$ & $12.2 \mathrm{a}$ & $74.2 \mathrm{c}$ & $13.5 \mathrm{a}$ \\
\hline
\end{tabular}

'Mean separation within columns by Ryan-Einot-Gabriel-Welsch multiple $\mathrm{F}$ test $(P \leq 0.05)$.

${ }^{x}$ LCSA $=$ limb cross-sectional area. 


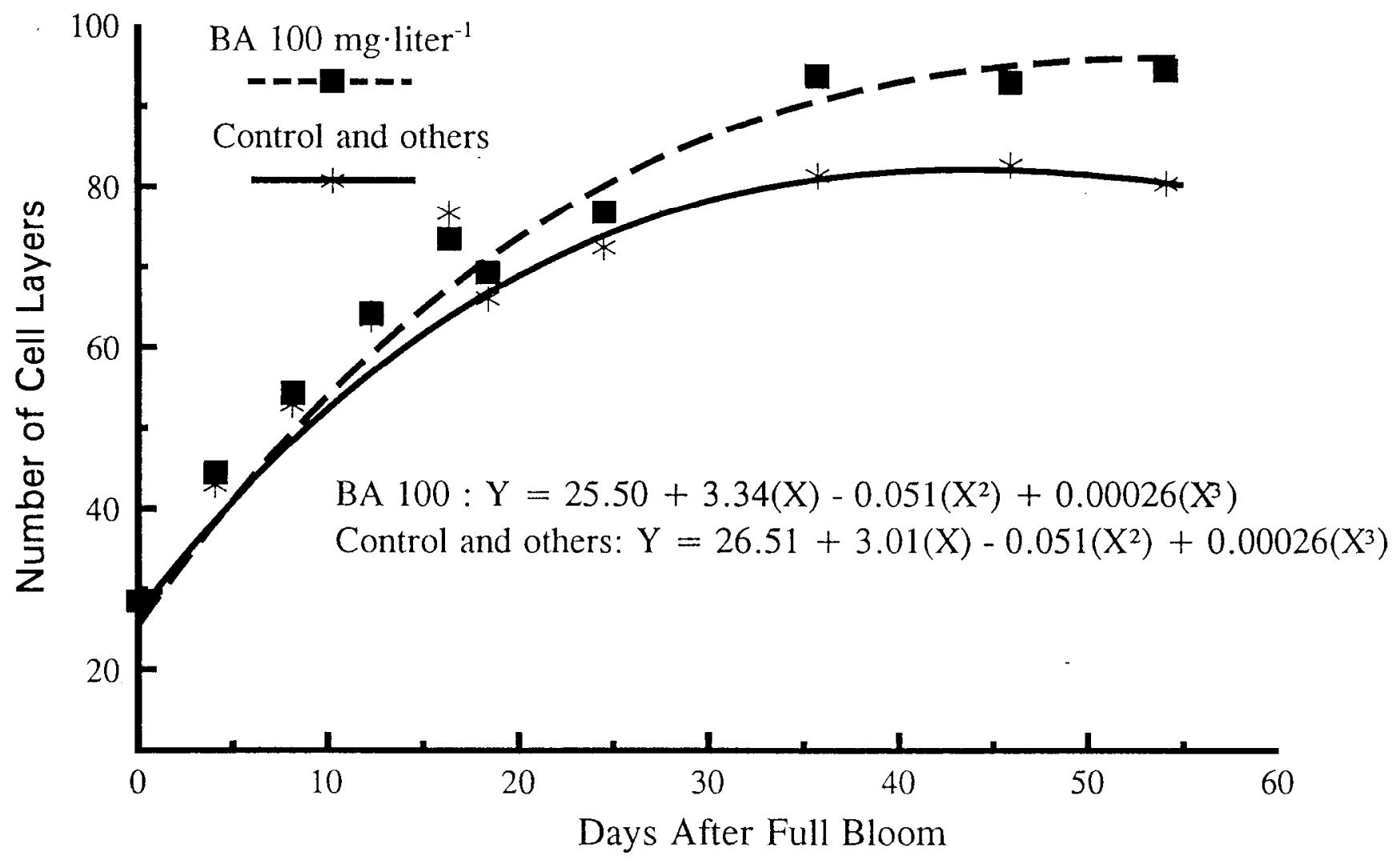

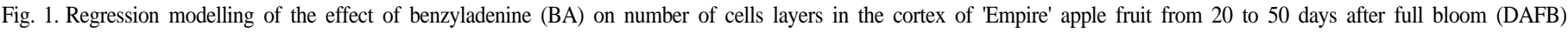
in 1990. Treatments were-applied 22 DAFB (mean fruit diameter $10.5 \mathrm{~mm}$ ).

Table 3. Effect of benzyladenine (BA), naphthaleneacetic acid (NAA), carbaryl (CB), and daminozide (DM) on the number of cell layers and cell diameter in the cortex of 'Empire' apples in 1991 (Expt. 2).

\begin{tabular}{lccc}
\hline \hline \multirow{2}{*}{$\begin{array}{l}\text { Treatment } \\
\left(\mathrm{mg}^{2} \cdot \text { liter }^{-1}\right)^{z, y}\end{array}$} & $\begin{array}{c}\text { No. of cell layers } \\
\text { 53 DAFB }\end{array}$ & \multicolumn{2}{c}{ Cell diam $(\mu \mathrm{m})$} \\
\cline { 3 - 4 } Control & $80 \mathrm{~b}$ & 53 DAFB & $134 \mathrm{DAFB}$ \\
BA 100 & $96 \mathrm{a}$ & $129 \mathrm{a}$ & $281 \mathrm{~b}$ \\
CB 1000 & $81 \mathrm{~b}$ & $131 \mathrm{a}$ & $265 \mathrm{bc}$ \\
NAA 15 & $79 \mathrm{~b}$ & $133 \mathrm{a}$ & $306 \mathrm{a}$ \\
DM 1500 & $76 \mathrm{~b}$ & $125 \mathrm{a}$ & $304 \mathrm{a}$ \\
\end{tabular}

${ }^{{ }^{2}}$ Treatments were applied 14 days after full bloom (mean fruit diameter $13.1 \pm 1.4 \mathrm{~mm})$

'Mean separation within columns by Ryan-Einot-Gabriel-Welsch multiple $\mathrm{F}$ test $(P \leq 0.05)$.

${ }^{x} \mathrm{DAFB}=$ days after full bloom.

cell division in this trial. Martin et al. (1964) also reported no effects on cell division in apple fruit when NAA was applied for thinning. The effect of $\mathrm{CB}$ on cell division in apple fruit tissue has not been reported previously. The absence of a celldivision effect from DM treatment may have been due to its being applied only once. Martin et al. (1968) observed reduced fruit cell numbers when DM was applied five times during the growing season.

Larger apples typically have larger cells due to greater cell expansion (Martin et al., 1964; Westwood et al., 1967). The increase in fruit size due to NAA or CB application appeared to result exclusively from increases in cell diameter related to reduced fruit set (Williams, 1979). In contrast, stimulation of cell division by BA contributed to larger fruit size by increasing the number of cells per fruit. The results reported here suggest that greater improvement in fruit size may be achieved when cell division is stimulated by the chemical thinner than when chemical thinning results only in reduced fruit set.

Larger fruit tend to have softer flesh, probably due to larger cell size (Greene et al., 1990). CB may have decreased firmness for this reason. Fruit from DM-treated trees were the smallest, firmest and had the smallest cell diameter, even though fruit set and yield were similar to the control (Edgerton and Hoffman, 1965; Greene et al., 1990). BA had no effect on flesh firmness at harvest in the 1991 trial, likely because cell diameter in BA-treated fruit was similar to the control. Greene and Autio (1989) and Greene et al. (1990) found that BA increased fruit flesh firmness, while Elfving and Lougheed (1994) reported little effect of BA on firmness after air storage.

The capacity of BA to increase cell division in the apple fruitlet when applied as a thinner has significant implications for commercial apple production. Large apples normally command a better price in the market; BA used as a chemical thinner has produced significant improvements in fruit size in several apple cultivars (Bound, et al., 1991; Elfving, 1989; Elfving and Cline, 1993a, 1993b; Greene and Autio, 1989; Greene et al., 1990; McLaughlin and Greene, 1984). Large apples composed of more numerous, smaller cells may be capable of maintaining equivalent or superior quality in long-term storage and after storage when compared to apples whose large size is solely a result of increases in cell size. The response of apples thinned with BA to longer-term controlledatmosphere storage and their ability to maintain poststorage quality merit further study. 


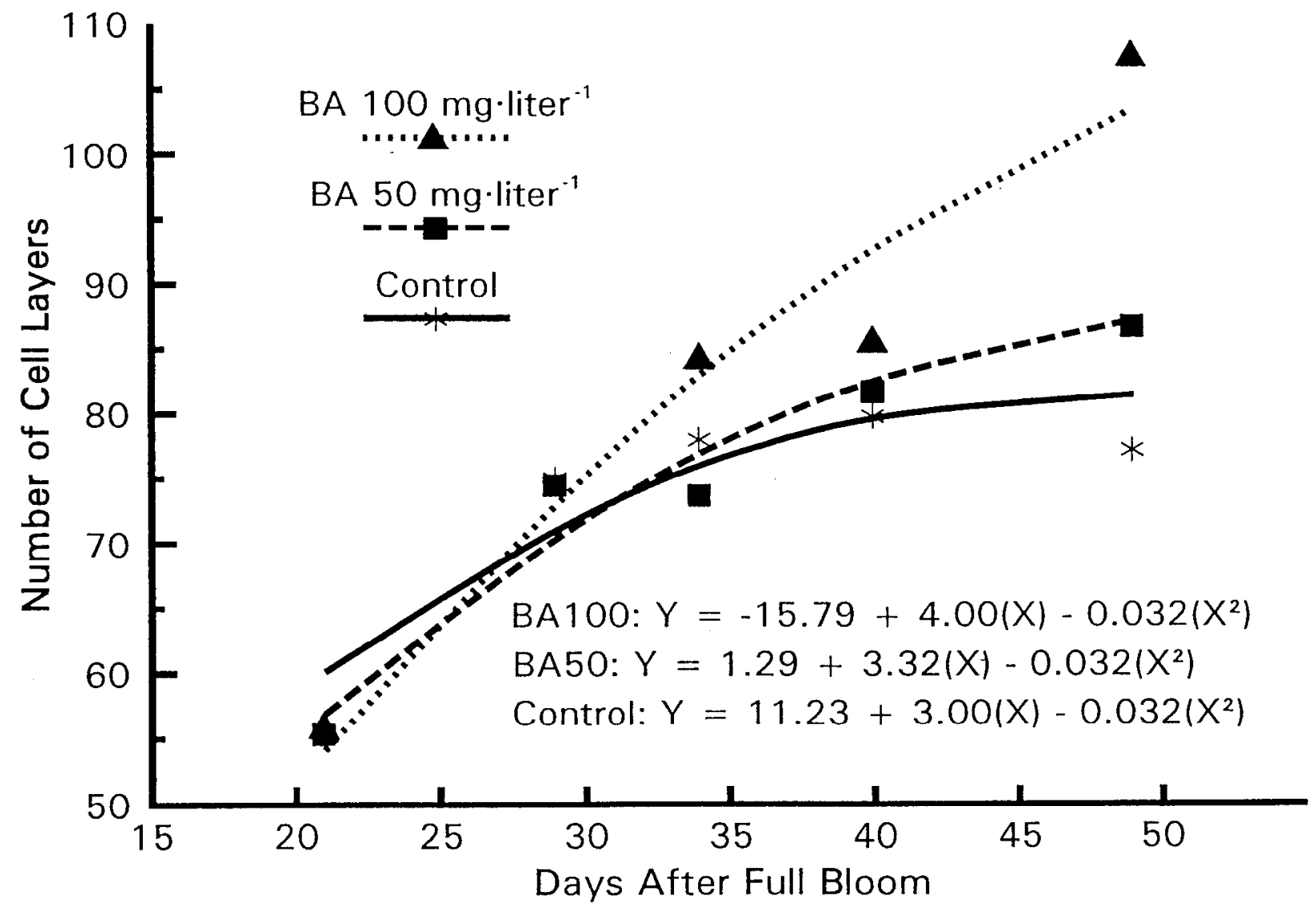

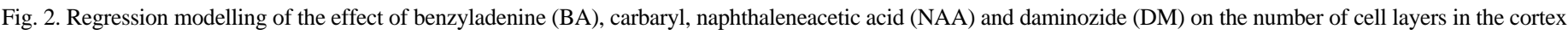

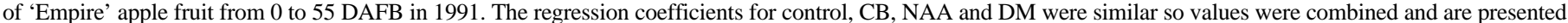
as "Control and others". Treatments were applied 22 DAFB (mean fruit diameter $13.1 \mathrm{~mm}$ ).

\section{Literature Cited}

Abbott Laboratories. 1993. Accel: Plant growth regulator solution. North Chicago, Ill.

Bain, J.M. and R.N. Robertson. 1951. The physiology of growth in apple fruits. I. Cell size, cell number and fruit development. Austral. J. Sci. Res. 4:75-91.

Bound, S.A., K.M. Jones, T.B. Koen, and M.J. Oakford. 1991. The thinning effect of benzyladenine on red 'Fuji' apple trees. J. Hort. Sci. 66:789-794.

Byers, R.E. and D.H. Carbaugh. 199 1. Effect of chemical thinning sprays on apple fruit set. HortTechnology 1:41-48.

Denne, M.P. 1960. The growth of apple fruitlets, and the effect of early thinning on fruit development. Ann. Bot. 24:397-406.

Denne, M.P. 1963a. Fruit development and some tree factors affecting it. N. Z. J. Bot. 1:265-294.

Denne, M.P. 1963b. A comparison between fruits of Cox's Orange Pippin from Kent, England, and Auckland, New Zealand. N.Z. J. Bot. 1:295300 .

Edgerton, L.J. and M.B. Hoffman. 1965. Some physiological responses of apple to N-dimethyl amino succinamic acid and other growth regulators. Proc. Amer. Soc. Hort. Sci. 86:28-36.

Elfving, D.C. 1989. N-(phenylmethyl)-1H-purine-6-amine (BA) as a chemical thinner for 'Idared' apple. Acta Hort. 239:357-362.

Elfving, D.C. 1991. Benzyladenine as a chemical thinner for apple. Compact Fruit Tree 24:73-74.

Elfving, D.C. and R.A. Cline. 1993a. Benzyladenine and other chemicals for thinning 'Empire' apple trees. J. Amer. Soc. Hort. Sci. 118:593-598.

Elfving, D.C. and R.A. Cline. 1993b. Cytokinin and ethephon affect crop load, shoot growth and nutrient concentration of 'Empire' apple trees. HortScience 28:1011-1014.

Elfving, D.C. and E.C. Lougheed. 1994. Storage responses of 'Empire' apples to benzyladenine and other chemical thinners. J. Amer. Soc. Hort. Sci. 119:253-257.

Elfving, D.C. and I. Schechter. 1993. Fruit count, fruit weight and yield relationships in 'Delicious' trees on nine rootstocks. HortScience 28:793-795. Forshey, C.G. and D.C. Elfving. 1977. Fruit numbers, fruit size and yield relationships in 'McIntosh' apples. J. Amer. Soc. Hort. Sci. 102:399402.

Forshey, C.G. and D.C. Elfving. 1979a. Branch samples for yield and fruit size comparisons in apple. HortScience 14:143-144.

Forshey, C.G. and D.C. Elfving. 1979b. Estimating yield and fruit numbers of apple trees from branch samples. J. Amer. Soc. Hort. Sci. 104:897-900.

Gardner, F.P., R.B. Pearce, and R.L. Mitchell. 1985. Physiology of crop plants. Iowa State Univ. Press, Ames, Iowa. p. 156-186.

Greene, D.W. and W.R. Autio. 1989. Evaluation of benzyladenine as a chemical thinner on 'McIntosh' apples. J. Amer. Soc. Hort. Sci. 114:68-73.

Greene, D.W., W.R. Autio, J.A. Erf, and Z.Y. Mao. 1992. Mode of action of benzyladenine when used as a chemical thinner on apples. J. Amer. Soc. Hort. Sci. 117:775-779.

Greene, D.W., W.R. Autio, and P. Miller. 1990. Thinning activity of benzyladenine on several apple cultivars. J. Amer. Soc. Hort. Sci. 115:394-400.

Letham, D.S. 1958. Cultivation of apple-fruit tissue in vitro. Nature 182:473-474.

Letham, D.S. 1963. Regulation of cell division in plant tissue. 1. Inhibitors and stimulants of cell division in developing fruits; their properties and activities in relation to the cell division period. N. Z. J. Bot. 1:336-350. Lombard, P.B., N.W. Callan, F.G. Dennis, Jr., N.E. Looney, G.C. Martin, A.R. Renquist, and E.A. Mielke. 1988. Towards a standardized nomenclature, procedures, values and units in determining fruit and nut yield performance. HortScience 23:813-817.

MacArthur, M. and R.H. Wetmore. 1941. Developmental studies of the 
apple fruit in the varieties McIntosh Red and Wagner. II. An analysis of development. Can. J. Res. 19:371-382.

Martin, D., T.L. Lewis, and J. Cerny. 1964. Apple fruit cell numbers in relation to cropping alternation and certain treatments. Austral. J. Agr. Res. 15:905-919.

Martin, D., T.L. Lewis, and J. Cerny. 1968. The effect of alar on fruit cell division and other characteristics in apples. Proc. Amer. Soc. Hort. Sci. 92:67-70.

McLaughlin, J.M. and D.W. Greene. 1984. Effects of BA, GA,+,, and daminozide on fruit set, fruit quality, vegetative growth, flower initiation, and quality of 'Golden Delicious' apple. J. Amer. Soc. Hort. Sci. 109:34-39.

O'Brien, T.P. and M.E. McCully. 1981. The study of plant structure, principles and selected methods. Termarcarphi Pty Ltd., Melborne, Australia.
Ontario Ministry of Agriculture and Food. 1990. Fruit production recommendations. Ont. Min. Agr. Food. Publ. 360.

Schechter, I., J.T.A. Proctor, and D.C. Elfving. 1993a. Characterization of seasonal fruit growth of 'Idared' apple. Scientia Hort. 54:203-210.

Schechter, I., J.T.A. Proctor, and D.C. Elfving. 1993b. Reappraisal of seasonal apple fruit growth. Can. J. Plant Sci. 73:549-556.

Tehrani, G., N.W. Miles, and D.C. Elfving. 1988. Training and pruning fruit trees. Ont. Min. Agr. Food. Publ. 392.

Westwood, M.N. 1993. Temperate-zone pornology. Timber Press, Portland, Ore. p. 217-274.

Westwood, M.N., L.P. Batjer, and H.D. Billingsley. 1967. Cell size, cell number, and fruit density of apples as related to fruit size, position in cluster, and thinning method. Proc. Amer. Soc. Hort. Sci. 91:51-62.

Williams, M.W. 1979. Chemical thinning of apples. Hort. Rev. 1:270300 . 